This document is confidential and is proprietary to the American Chemical Society and its authors. Do not copy or disclose without written permission. If you have received this item in error, notify the sender and delete all copies.

\title{
Improving the Catalytic Performance of an Artificial Metalloenzyme by Computational Design
}

\begin{tabular}{|c|c|}
\hline Journal: & Journal of the American Chemical Society \\
\hline Manuscript ID: & ja-2015-06622s.R1 \\
\hline Manuscript Type: & Article \\
\hline Date Submitted by the Author: & 28-Jul-2015 \\
\hline Complete List of Authors: & $\begin{array}{l}\text { Heinisch, Tillmann; University Basel, Chemistry } \\
\text { Pellizzoni, Michela; University Basel, Chemistry } \\
\text { Dürrenberger, Marc; University of Basel, Inorganic Chemistry } \\
\text { Tinberg, Christine; University of Washington, Department of Biochemistry } \\
\text { Köhler, Valentin; University Basel, Chemistry } \\
\text { Klehr, Juliane; University Basel, Chemistry } \\
\text { Häussinger, Daniel; Universität Basel, Chemie } \\
\text { Baker, David; University of Washington, Department of Biochemistry } \\
\text { Ward, Thomas; University of Basel, Department of Chemistry }\end{array}$ \\
\hline
\end{tabular}

SCHOLARONE ${ }^{\text {Mx }}$

Manuscripts 
ABSTRACT: Artifical metalloenzymes combine the reactivity of small molecule catalysts with the selectivity of enzymes, and new methods are required to tune the catalytic properties of these systems for an application of interest. Structure-based computational design could help to identify amino acid mutations leading to improved catalytic activity and enantioselectivity. Here we describe the application of Rosetta Design for the genetic optimization of an artificial transfer hydrogenase (ATHase hereafter $),\left[\left(\eta^{5}-\mathrm{Cp}^{*}\right) \operatorname{Ir}(\right.$ pico $\left.) \mathrm{Cl}\right] \subset \mathrm{WT}$ hCA II $\left(\mathrm{Cp}^{*}=\right.$ $\mathrm{Me}_{5} \mathrm{C}_{5}^{-}$), for the asymmetric reduction of a cyclic imine, the precursor of salsolsidine. Based on a crystal structure of the ATHase, computational design afforded four hCAII variants with protein backbone-stabilizing and hydrophobic cofactor-embedding mutations. In dansylamide-competition assays, these designs showed 46-64fold improved affinity for the iridium pianostool complex $\left[\left(\eta^{5}-\mathrm{Cp} *\right) \operatorname{Ir}(\right.$ pico $\left.) \mathrm{Cl}\right]$. Gratifyingly, the new designs yielded a significant improvement both in activity and enantioselectivity (from $70 \%$ ee (WT hCA II) to up to 92 $\%$ ee and a fourfold increase in total turnover number) for the production of $(S)$-salsolidine. Introducing additional hydrophobicity in the $\mathrm{Cp}^{*}$-moiety of the Ir-catalyst provided by adding a propyl substituent on the $\mathrm{Cp}^{*}$ moiety yields the most $(S)$-selective (96\% ee) ATHase reported to date. X-ray structural data indicate that the high enantioselectivity results from embedding the piano stool moiety within the protein, consistent with the computational model.

\section{Introduction}

Over the past decade, artificial metalloenzymes have gained attention as attractive alternatives to both homogeneous catalysts and enzymes. ${ }^{1-11}$ These hybrid catalysts result from anchoring an organometallic cofactor within a protein environment, thus augmenting the enzymatic repertoire with reactions or reaction pathways accessible only to organometallic catalysts. ${ }^{12-28}$ Optimization of the catalytic performance can be achieved by combining both chemical means (i.e. variation of the ligand bound to the metal and of the spacer between the anchor and the ligand) with genetic means (amino acid mutation), Figure 1a.

Methods to optimize first generation artificial metalloenzymes (hereafter ArMs) are necessary to achieve desired catalytic properties. Traditional directed evolution efforts are powerful but limited because of the small number of variants that can be screened in a typical experiment. ${ }^{11,15,29-32}$ This shortcoming is partially imposed by the requirement of purified protein samples to ensure the activity of ArMs. Most mutagenesis strategies to date have thus relied on structure gazing and educated guessing to identify potential single- and double mutants that may improve the catalytic performance.

Computational design offers an alternative to high throughput directed evolution screening efforts. ${ }^{33-35}$ The library-size limitation of artificial metalloenzymes can be circumvented by using computational design principles to reduce the vast sequence landscape of the catalystprotein interface to a small number of variants that can be characterized experimentally. Computational methods that rapidly optimize the entire sequence space of the cofactor-binding site may offer a more comprehensive 


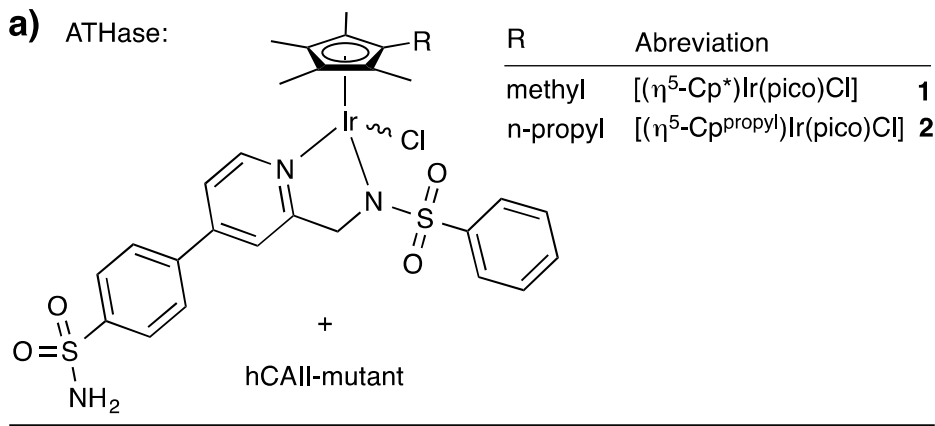

b)

\begin{tabular}{lccccccccc} 
WT & $\frac{60}{\mathrm{~L}}$ & $\frac{65}{\mathrm{~A}}$ & $\frac{67}{\mathrm{~N}}$ & $\frac{69}{\mathrm{E}}$ & $\frac{92}{\mathrm{Q}}$ & $\frac{140}{\mathrm{~L}}$ & $\frac{197}{\mathrm{~L}}$ & $\frac{205}{\mathrm{C}}$ & $\frac{K_{\mathrm{d}} \mathbf{1}[\mathrm{nM}]}{21.2 \pm 1.6}$ \\
\cline { 1 - 2 } & & & & & & M & M & S & n.d. \\
a2 & & & & & & $\mathrm{M}$ & $\mathrm{M}$ & $\mathrm{S}$ & $0.96 \pm 0.17$ \\
a3 & $\mathrm{V}$ & & $\mathrm{W}$ & $\mathrm{Y}$ & & & & $\mathrm{S}$ & n.d. \\
a4 & $\mathrm{V}$ & $\mathrm{T}$ & $\mathrm{W}$ & & $\mathrm{F}$ & & $\mathrm{M}$ & & $0.418 \pm 0.041$ \\
d1 & $\mathrm{V}$ & $\mathrm{T}$ & $\mathrm{W}$ & $\mathrm{Y}$ & $\mathrm{F}$ & & & $\mathrm{S}$ & $0.456 \pm 0.043$ \\
d2 & $\mathrm{V}$ & $\mathrm{T}$ & $\mathrm{W}$ & & $\mathrm{F}$ & & $\mathrm{M}$ & $\mathrm{S}$ & $0.427 \pm 0.048$ \\
d3 & $\mathrm{V}$ & $\mathrm{T}$ & $\mathrm{W}$ & $\mathrm{Y}$ & $\mathrm{F}$ & & $\mathrm{M}$ & $\mathrm{S}$ & $0.332 \pm 0.057$ \\
d4 & $\mathrm{V}$ & $\mathrm{T}$ & $\mathrm{W}$ & $\mathrm{Y}$ & $\mathrm{F}$ & $\mathrm{M}$ & $\mathrm{M}$ & $\mathrm{S}$ & $\mathrm{n} . \mathrm{d}$.
\end{tabular}

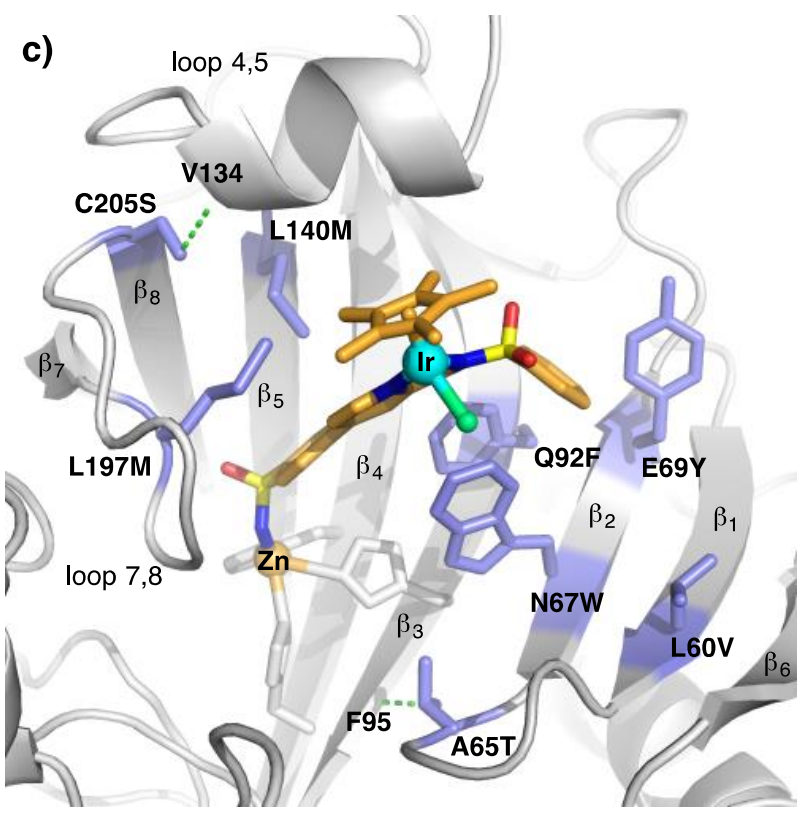

Figure 1: Sulfonamide iridium pianostool cofactors (a) and hCAII variants used in this study, including affinities of selected 1 $\subset$ hCAII mutants (b). Model of Rosetta Design d4-based on crystal structure of complex $\left[\left(\eta^{5}-\mathrm{Cp} *\right) \operatorname{Ir}(\right.$ pico $\left.) \mathrm{Cl}\right] \mathbf{1} \subset \mathrm{WT}$ hCA II (PDB 3ZP9) (c). Designed backbone-stabilizing H-bonds are represented as green dashed lines.

approach to designing ArMs with improved performance. The Rosetta protein design software is a versatile tool for the structure-based computational design of proteinprotein, ${ }^{36}$ protein-small molecule ${ }^{37}$ and protein-metal ${ }^{30,38}$ interactions, including the creation of artificial enzymes. ${ }^{39-42}$ Recently, Baker and coworkers reported the de novo design of a picomolar affinity binding protein for the steroid digoxigenin. ${ }^{37}$ Explicit design of $\mathrm{H}$ bonding and hydrophobic interactions resulted in a highly shape-complementary, low micromolar affinity binding protein. Three rounds of directed evolution increased binding affinity by more than three orders of magnitude, and deep mutational scanning showed that many of the first shell binding site residues of the design were optimal for binding. Intrigued by that level of success, we hypothesized that Rosetta may also be used to improve a cofactor binding site of first generation ArMs. We reasoned that a more tightly bound organometallic cofactor may lead to a better defined first and second coordination sphere that may improve catalytic performance.

We recently reported the assembly of Noyori-type pianostool complex $\left[\left(\eta^{5}-\mathrm{Cp}^{*}\right) \operatorname{Ir}(\mathrm{pico}) \mathrm{Cl}\right] \mathbf{1}$ (Figure 1a,c) within wild type human carbonic anhydrase II (hCAII hereafter). ${ }^{43}$ The ArM catalyzes the asymmetric transfer hydrogenation of the salsolidine precursor (a cyclic imine) into the chiral alkaloid salsolidine with moderate enantioselectivity (70\% ee $(S)$-salsolidine) and a total turnover number of 9 at $4{ }^{\circ} \mathrm{C}$ (Table 1, entry 4). Although the Ir-cofactor binds to hCAII with low nanomolar affini- ty, the crystal structure of the hybrid catalyst revealed that the $\{\mathrm{Cp} * \mathrm{Ir}\}$-moiety is only $30 \%$ occupied presumably due to partial dissociation and/or shallow potential energy surface within the active site. We speculate that the WT hCA II has limited influence over the active site geometry, leading to a poorly defined "active site" around the $\{\mathrm{Ir}-\mathrm{H}\}$-catalytic moiety and resulting in a modest activity and selectivity.

Herein we report our efforts to improve the catalytic performance of $\left[\left(\eta^{5}-\mathrm{Cp} *\right) \operatorname{Ir}(\right.$ pico $\left.) \mathrm{Cl}\right] \mathbf{1} \subset \mathrm{hCA}$ II by using the computational design software Rosetta to tailor the second coordination sphere around the iridium cofactor.

\section{Results and Discussion}

The enzyme design module ${ }^{45}$ of Rosetta was used to identify potential mutations that stabilize the $\left[\left(\eta^{5}-\right.\right.$ $\left.\mathrm{Cp}^{*}\right) \operatorname{Ir}($ pico)Cl] $\mathbf{1} \subset \mathrm{hCA}$ II hybrid. The crystal structure of complex $\mathbf{1} \subset$ WT hCAII (PDB ID 3ZP9) was relaxed ${ }^{46}$ and the sequence of the protein was optimized for protein-cofactor interaction energy using fixed-backbone sequence design. ${ }^{45}$ An example RosettaScripts ${ }^{47}$ XML design protocol is provided in the Supplementary Information. During design calculations, the native residue energies were up-weighted by 1.5 relative to their standard weight in the score 12 or enzdes weight set to prevent protein destabilization. Zinc-coordinating His residues were fixed in their native conformations. Designable residues were restricted to those within $10 \AA$ of the Ircatalyst, and residues were not allowed 
Table 1: Influence of hCAII variants on transfer hydrogenation of isoquinoline substrates with ATHase. ${ }^{\mathrm{a}}$

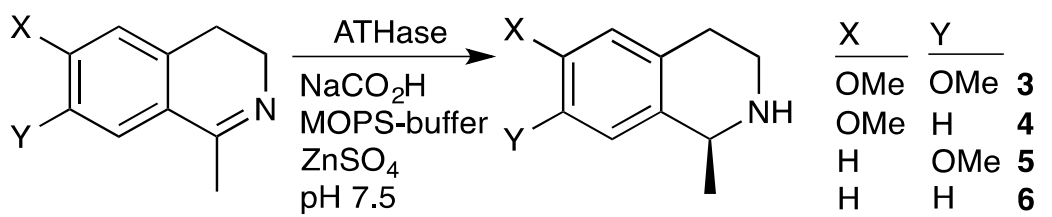

\begin{tabular}{|c|c|c|c|c|c|c|c|}
\hline Entry & hCAII-mutant & $\begin{array}{l}\text { Metal cata- } \\
\text { lyst }\end{array}$ & Substrate & $\begin{array}{l}\text { Temperature } \\
{\left[{ }^{\circ} \mathrm{C}\right]}\end{array}$ & $\begin{array}{l}\text { Reaction } \\
\text { Time [h] }\end{array}$ & TON & ee [\%] \\
\hline $1^{\mathrm{b}}$ & no protein & 1 & 3 & RT & 18 & 15 & $\mathrm{rac}$ \\
\hline $2^{b}$ & no protein & 2 & 3 & RT & 24 & 10 & $\mathrm{rac}$ \\
\hline 3 & WT & 1 & 3 & RT & 18 & 25 & $58(S)$ \\
\hline $4^{b, c, d}$ & WT & 1 & 3 & 4 & 44 & 9 & $70(S)$ \\
\hline 6 & a1 & 1 & 3 & 4 & 96 & 37 & $85(S)$ \\
\hline 7 & $\mathrm{a} 2$ & 1 & 3 & 4 & 96 & 43 & $86(S)$ \\
\hline 8 & $\mathrm{a} 3$ & 1 & 3 & 4 & 96 & 24 & $74(S)$ \\
\hline 9 & $\mathrm{a} 4$ & 1 & 3 & RT & 18 & 100 & $90(S)$ \\
\hline 10 & $\mathrm{a} 4$ & 1 & 3 & 4 & 96 & 98 & $94(S)$ \\
\hline 11 & $\mathrm{~d} 1$ & 1 & 3 & RT & 18 & 91 & $87(S)$ \\
\hline 12 & $\mathrm{~d} 1$ & 1 & 3 & 4 & 96 & 85 & $91(S)$ \\
\hline 13 & $\mathrm{~d} 2$ & 1 & 3 & RT & 18 & 72 & $84(S)$ \\
\hline 14 & $\mathrm{~d} 2$ & 1 & 3 & 4 & 96 & 71 & $87(S)$ \\
\hline 15 & $\mathrm{~d} 3$ & 1 & 3 & RT & 18 & 81 & $88(S)$ \\
\hline 16 & d3 & 1 & 3 & 4 & 96 & 77 & $91(S)$ \\
\hline 17 & $\mathrm{~d} 4$ & 1 & 3 & 4 & 96 & 78 & $92(S)$ \\
\hline 18 & $\mathrm{a} 2$ & 2 & 3 & RT & 24 & 31 & $69(\mathrm{~S})$ \\
\hline 19 & $\mathrm{~d} 3$ & 2 & 3 & 4 & 288 & 38 & $94(S)$ \\
\hline 20 & $\mathrm{~d} 4$ & 2 & 3 & 4 & 288 & 59 & $96(S)$ \\
\hline 21 & $\mathrm{a} 2$ & 1 & 4 & 4 & 192 & 82 & $85(S)$ \\
\hline 22 & $\mathrm{~d} 1$ & 1 & 4 & RT & 20 & 84 & $60(S)$ \\
\hline 23 & $\mathrm{a} 2$ & 1 & 5 & 4 & 192 & 99 & $90(S)$ \\
\hline 24 & $\mathrm{~d} 1$ & 1 & 5 & RT & 22 & 91 & $64(S)$ \\
\hline 25 & $\mathrm{a} 2$ & 1 & 6 & 4 & 96 & 80 & $75(S)$ \\
\hline 26 & $\mathrm{~d} 1$ & 1 & 6 & 4 & 96 & 98 & $74(R)$ \\
\hline
\end{tabular}

${ }^{a}$ Reactions were carried out in the presence of $9.1 \mathrm{mM}$ substrate, $0.104 \mathrm{mM}$ hCAII-mutant, $0.091 \mathrm{mM}$ metal catalyst (1 mol\%), $2.73 \mathrm{M}$ sodium formate, $0.36 \mathrm{M}$ MOPS buffer (pH 7.5) and $1.04 \mathrm{mM} \mathrm{ZnSO}_{4}$ unless otherwise indicated. ${ }^{\text {b }} \mathrm{No} \mathrm{ZnSO}_{4}$ was added. ${ }^{c} 4 \mathrm{mM}$ substrate were used. ${ }^{\mathrm{d}}$ data from ref. ${ }^{48}$ See Figure 1 for definition of mutations.

to mutate to cysteine, aspartate, or glutamate. The ligand was extracted from PDB ID 3ZP9 and was converted to a Rosetta readable parameters file format using the molfile_to_params application of Rosetta. Lennard-Jones and solvation parameters for the Ir atom were taken from the Unified Force Field. ${ }^{49}$ Designs were scored using score 12 and the enzdes weights set with or without electrostatics. Ten separate trajectories of Monte Carlo design were run, and four designs were selected for experimental characterization based on total energy, manual inspection, occurrence of mutated residue identities in a multiple sequence alignment of hCA II, and the computed probability of maintaining mutated residue side chain conformations in the absence of the cofactor $(\mathbf{d 1}, \mathbf{d} 2, \mathbf{d} 3$, d4, Figure 1 b,c)..$^{50}$

The four selected designs include between six and eight amino acid mutations, predominantly of hydrophobic nature that either provide additional shape complementarity and packing interactions between the protein and the cofactor (N67W, E69Y, Q92F, L140M, L197M) or stabilize the protein backbone (C205S, A65T, L60V) (Figure $1 \mathrm{~b}, \mathrm{c})$. These mutations are clustered within two regions on the central $\beta$-sheet of the protein (Figure 1c). Key mutations that directly contact the ligand are L140M on $\beta$-strand 5 and L197M in loop 7,8, which pack against the coplanar biaryl moiety of the ligand. Residue C205S at the end of loop 7,8 is designed to form an H-bond with the carbonyl oxygen of V134 in loop 4,5. Rigidifying the 
relative orientation of these loops through this hydrogen bond likely helps to hold the cofactor in a more defined orientation. Residues N67W, E69Y and Q92F are located on $\beta$-strands 2 and 3 which interact with the biaryl group and the chelating phenylsulfonamide. Mutation A65T on $\beta$-strand 2 is designed to form an $\mathrm{H}$-bond with the carbonyl oxygen of F95.

Mutations were introduced into hCAII by stepwise mutagenesis of individual amino acids. Besides the four Rosetta hCAII designs, we also present four additional mutants that include only some of the Rosetta-predicted mutations (a1, a2, a3, a4, Figure 1b) but were particularly successful in terms of catalytic performance and might help to assess the impact of individual sites.

The affinities of five of the hCAII variants for the organometallic catalyst $\left[\left(\eta^{5}-\mathrm{Cp}^{*}\right) \operatorname{Ir}(\mathrm{pico}) \mathrm{Cl}\right] \mathbf{1}$ were determined by colorimetric competition assay with dansylamide (Figure 1b, Supporting Table S7, Supporting Figures S4 and S5). ${ }^{51,52}$ All designs showed increased affinities for the cofactor relative to wild-type hCAII. The best Rosetta design, d3, binds $\left[\left(\eta^{5}-\mathrm{Cp}^{*}\right) \operatorname{Ir}(\right.$ pico $\left.) \mathrm{Cl}\right] \mathbf{1} \sim 64$ times more tightly than WT hCA II does (0.33 nM vs. 21 $\mathrm{nM}$ ). This design contains backbone stabilizing residues L60V, A65T, L197M and C205S and aromatic mutations N67W, E69Y and Q92F, which provide shape complementarity with the ligand from one side. Back-mutation of methionine L197M on $\beta$-strand 5, as in design d1, reduces the affinity by 1.4 -fold. Similarly back-mutation of E69Y as in $\mathbf{d} 2$ reduces the affinity 1.3-fold, highlighting the success of the Rosetta design. Reversion of residue $\mathrm{C} 205 \mathrm{~S}$ into native cysteine in $\mathbf{d} 2$ yields the design precursor a4, which has virtually identical cofactor affinity. Interestingly, even a reduced set of only three mutations engineered near one face of the cofactor binding site can improve the affinity 22-fold over the wild type protein, as highlighted with a2. Together, these results suggest that Rosetta Design can be used to improve the affinities of organometallic cofactor-protein interactions by introduction of bulky hydrophobic residues in the cofactor binding site combined with backbone-stabilizing mutations.

Next, we investigated how the mutants perform in the asymmetric transfer hydrogenation of a model substrate, the salsolidine precursor 3 (Table 1). Gratifyingly, the hCAII mutants with higher affinity for $\left[\left(\eta^{5}-\right.\right.$ $\left.\mathrm{Cp}^{*}\right) \operatorname{Ir}($ pico $\left.) \mathrm{Cl}\right] \mathbf{1}$ than wild type are both more active and more enantioselective. Rosetta designs d1, d2 and d3, which have 46-64 fold improved affinity, produce $(S)$-salsolidine with 91,87 and $91 \%$ ee at $4{ }^{\circ} \mathrm{C}$, respectively (wild type: $70 \%$ ee; Table 1 compare entries 4, 12, 14 and 16). Performing catalysis at $298 \mathrm{~K}$ leads to significantly higher turnover numbers (TON hereafter): from 25 for WT-hCAII to 91, 72 and 81 for designs d1, d2 and d3, respectively (Table 1 entries, 3, 11, 13, 15). Under the same conditions, the free $\left[\left(\eta^{5}-\mathrm{Cp}^{*}\right) \operatorname{Ir}(\right.$ pico $\left.) \mathrm{Cl}\right] \mathbf{1}$ shows only 15 TON. The design precursor a4, which differs from $\mathbf{d} 2$ by only one mutation (C205S) and has virtually identical cofactor affinity, is the best catalyst, producing $(S)$-salsolidine with $94 \%$ ee and a TON of 98 at $4{ }^{\circ} \mathrm{C}$. This illustrates how distant residues can have significant impact on enzyme performance. Saturation kinetic parameters were determined for the two most active mutants a4 and d1 $\left(k_{\text {cat }}=0.29 \pm 0.02 \mathrm{~min}^{-1}, K_{\mathrm{M}}=\right.$ $23 \pm 3.4 \mathrm{mM}$ and $k_{\text {cat }}=0.16 \pm 0.01 \mathrm{~s}^{-1}, K_{\mathrm{M}}=20 \pm 2.5$ $\mathrm{mM}$, respectively, Supporting Figure S2). Comparing designs a4 and d1, we hypothesize that the presence of a glutamate (vs. tyrosine) at position 69 for a4 (vs. d1) offers favourable interactions with the iminium form of the substrate, contributing to the twofold rate enhancement. In contrast to wild type hCAII ${ }^{43}$ and a number of related streptavidin ATHases, ${ }^{44}$ no substrate inhibition is encountered for a4 and d1, even at $100 \mathrm{mM}$ substrate concentration.

Taking advantage of the versatile chemogenetic optimization potential of artificial metalloenzymes, we reasoned that increased hydrophobic interactions between the cofactor and the protein may also be provided by introducing a bulkier propyl substituent on the $\eta^{5}$-arene cap. The metal center of metallocofactor $\left[\left(\eta^{5}-\right.\right.$ $\left.\mathrm{Cp}^{\text {propyl }}\right) \operatorname{Ir}($ pico)Cl] 2 (Figure 1a) is more electron-rich and bulkier than $\left[\left(\eta^{5}-\mathrm{Cp}^{*}\right) \operatorname{Ir}(\mathrm{pico}) \mathrm{Cl}\right] \mathbf{1}$, hampering metal-hydride formation. This trend is reflected in the slightly reduced activity of $\left[\left(\eta^{5}-\mathrm{Cp}^{\text {propyl }}\right) \operatorname{Ir}(\right.$ pico $\left.) C l\right] 2$ vs. [ $\left(\eta^{5}-\right.$ $\left.\mathrm{Cp}^{*}\right) \operatorname{Ir}($ pico $\left.) \mathrm{Cl}\right] \mathbf{1}$ (Table 1 , entries 1 and 2). The hCAII mutants follow the same general activity and enantioselectivity trends for cofactors $\left[\left(\eta^{5}-\mathrm{Cp}^{\text {propyl }}\right) \operatorname{Ir}(\right.$ pico $\left.) \mathrm{Cl}\right] \mathbf{2}$ and $\left[\left(\eta^{5}-\mathrm{Cp}^{*}\right) \operatorname{Ir}(\right.$ pico $\left.) \mathrm{Cl}\right] \mathbf{1}$ (Table 1 and Supporting Table S3). The most $(S)$-selective ATHase (96\% ee) was obtained combining Rosetta design d4 with $\left[\left(\eta^{5}\right.\right.$ $\left.\mathrm{Cp}^{\text {propyl }}\right) \operatorname{Ir}($ pico $\left.) C l\right] ~ 2$. It is interesting to note that the streptavidin-based ATHases typically afford the $(R)$ salsolidine. The best $(S)$-selective streptavidin-based ATHase $(78 \%$ ee $)$ is $\left[\left(\eta^{5}-\mathrm{Cp}^{*}\right) \operatorname{Ir}(\right.$ Biot- $p$-L) $\mathrm{Cl}] \subset$ S112K. ${ }^{17}$

Despite repeated attempts to crystalize all variants, only the hCAII $\mathbf{a} 2$ mutant yielded X-ray quality crystals. This construct comprises amino acid mutations L140M, L197M and C205S. Diffraction data were collected at the synchrotron to 1.4 - $1.6 \AA$ resolution for three crystals: i) apo-a2, ii) $\left[\left(\eta^{5}-\mathrm{Cp}^{*}\right) \operatorname{Ir}(\right.$ pico $\left.) \mathrm{Cl}\right] \mathbf{1} \subset \mathbf{a} 2$ and iii) $\left[\left(\eta^{5}-\right.\right.$ $\mathrm{Cp}^{\text {propyl }}$ ) Ir(pico)Cl] $\mathbf{2} \subset \mathbf{a} 2$ (Supporting Table S4 and S5). The latter two were obtained by soaking apo-protein crystals with the corresponding Ir-catalyst. For all three crystal structures, the overall protein structure is virtually identical to WT hCAII $(0.28-0.30 \AA$ RMSD for C $\alpha$ and $\mathrm{C} \beta$ ). For apo-a2, high side chain flexibility is found for residues L140M and L197M: these adopt two alternative conformations (Supporting Figure S3a and b). The side chain of $\mathrm{C} 205 \mathrm{~S}$ is rotated $\sim 90^{\circ}$ around the $\mathrm{C} \alpha-\mathrm{C} \beta$ bond relative to the wild type cysteine and forms an $\mathrm{H}$-bond with the carbonyl oxygen of V134 which links loop 7,8 with loop 4,5. For both structures containing the Ir- 
cofactor-bound complexes, residual electron density in the $2 \mathrm{Fo}-\mathrm{Fc}$ map is observed in the cone-shaped catalytic cavity, indicating the presence of the cofactor. In structure $\left[\left(\eta^{5}-\mathrm{Cp}^{*}\right) \operatorname{Ir}(\right.$ pico $\left.) \mathrm{Cl}\right] \mathbf{1} \subset \mathbf{a} \mathbf{2}$, the cofactor was modeled as previously described for the equivalent $\left[\left(\eta^{5}-\right.\right.$ $\left.\mathrm{Cp}^{*}\right) \operatorname{Ir}($ pico)Cl] $\mathbf{1} \subset \mathrm{WT}$ hCAII (Supporting Figure S3a).

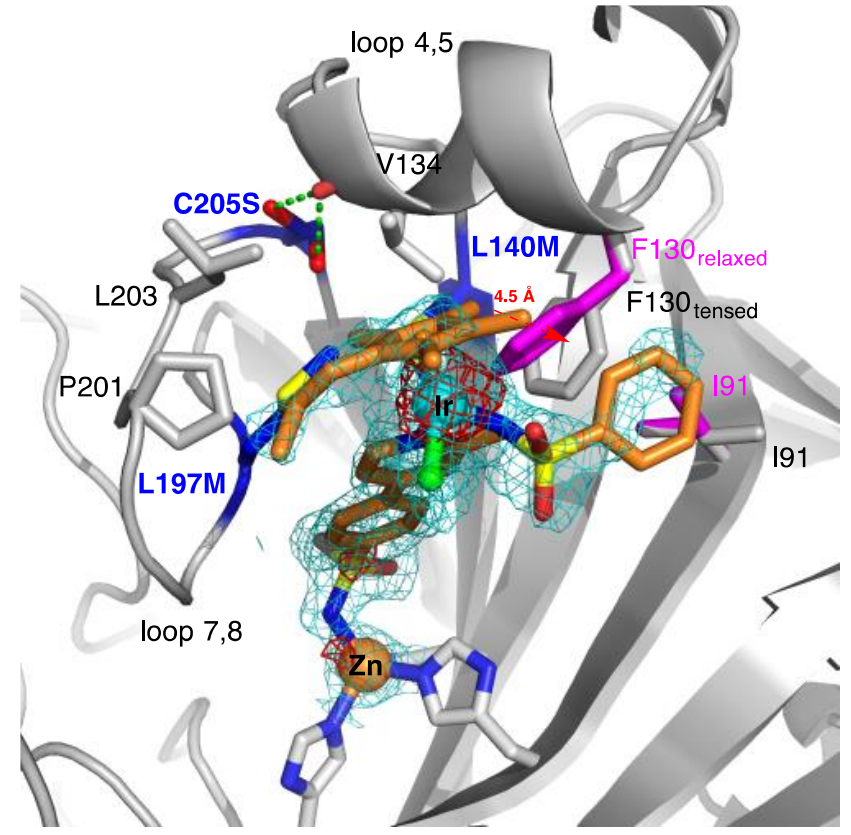

Figure 2: X-ray crystal structure of $\left[\left(\eta^{5}-\right.\right.$ $\left.\mathrm{Cp}^{\text {propyl }}\right) \operatorname{Ir}($ pico)Cl] $\mathbf{2} \subset$ hCAII a2 (PDB 5BRU). The Ircofactor is depicted as stick in orange (iridium, cyan sphere; chloride, green sphere) and is contoured with 2Fo-Fc electron density in blue at $1 \sigma$ and anomalous difference density in red at $3 \sigma$. Mutated amino acid side chains are represented as blue sticks. Upon catalyst binding, the side chain conformation of residue F130 switches from a relaxed state (magenta stick model; modeled in the crystal structure of apo-hCAII a2, PDB $5 \mathrm{BRW}$ ) to a tense state (grey stick model) through $60^{\circ}$ rotation about the $\mathrm{C} \beta-\mathrm{C} \gamma$ bond. As a consequence, the side chain of residue 191 undergoes rotation from an eclipsed to a trans conformation. Residues P201, L203 and V134 are involved in hydrophobic interactions with the cofactor's C $\mathrm{p}^{\text {propyl }}$ group. Loops 4,5 and 7,8 interact via an $\mathrm{H}-$ bond between $\mathrm{C} 205 \mathrm{~S}-\mathrm{O} \gamma$ and $\mathrm{V} 134-\mathrm{O}_{\text {carbonyl. }}$

Full atomic occupancy was found for the anchoring benzene sulfonamide moiety.

However, limited density for the methylpyridine, $\mathrm{Cp} *, \mathrm{Cl}$ and the terminal phenylsulfonamide suggests partial dissociation of the metal moiety and increased flexibility of the methylpyridine and the terminal phenylsulfonamide. The latter group was modeled in an Ir-binding eclipsed (30\% occupancy) and non-binding anticlinal conformation ( $70 \%$ occupancy). In this structure, the cofactor causes the L140M side chain to adopt one conformation only, whereas L197M, which is closer to the flexible methylpyridine, adopts two conformations as in the apo-a2 structure. C205S, which adopts the same conformation in the cofactor-bound and apo forms, forms an $\mathrm{H}$-bond with the carbonyl oxygen of V134. For $\left[\left(\eta^{5}-\right.\right.$ $\left.\mathrm{Cp}^{\text {propyl }}\right) \operatorname{Ir}($ pico)Cl] $\mathbf{2} \subset \mathbf{a} \mathbf{2}$, all atoms of the cofactor could be modeled with $100 \%$ occupancy (Figure 2, and Supporting Figure S3b). The metal complex adopts $(R)$ configuration. Upon cofactor binding, an attractive $\mathrm{CH} / \pi$ interaction between I91-C $\delta$ and the F130-phenyl is disrupted (Figure 2, magenta) but is compensated by a newly formed $\mathrm{CH} / \pi$ bond between the methyl group of (propyl) $\mathrm{C}_{5} \mathrm{Me}_{4}$ and F130-phenyl (Figure 2, red dashed arrow). A similar interaction was also present in the crystal structure of a $\left[\left(\eta^{6}-\mathrm{C}_{6} \mathrm{Me}_{6}\right) \mathrm{Ru}\right.$ (bispyridine $\left.)\right] \subset \mathrm{WT}$ hCAII. ${ }^{53}$ Additionally, in this structure, both side chains L140M and L197M adopt a single conformation (Supporting Figure S3b). The side chain of C205S adopts both conformations observed in the $\left[\left(\eta^{5}-\mathrm{Cp}^{*}\right) \operatorname{Ir}(\mathrm{pico}) \mathrm{Cl}\right]$ $\mathbf{1} \subset \mathrm{WT}$ hCAII and in apo-a2 which forms an $\mathrm{H}$-bond with the carbonyl oxygen of V134.

To gain insight into substrate recognition by the ATHase active site, derivatives of the salsolidine precursor with a single methoxy group in position 6- (4) or 7(5) and the desmethoxy substrate 6 were tested for transfer hydrogenation with selected hybrid catalysts. The ATHase [ $\left(\eta^{5}-\mathrm{Cp}^{*}\right) \operatorname{Ir}($ pico $\left.) \mathrm{Cl}\right] \mathbf{1} \subset \mathbf{a} 2$ affords enantioenriched $(S)$-amines with 86, 85, 90 and $75 \%$ ee for substrates 3, 4, 5 and 6, respectively (Table 1, entries 7, 21, 23 and 25). Similarly, screening [ $\left(\eta^{5}-\mathrm{Cp}^{*}\right) \operatorname{Ir}($ pico $\left.) \mathrm{Cl}\right] \mathbf{1} \subset$ d1 with substrates $\mathbf{3 , 4}, \mathbf{5}$ affords the corresponding $(S)$ amines in 87, 60 and $64 \%$ ee respectively (Table 1, entries 11, 22 and 24). Strikingly, the desmethoxy substrate 6 affords the opposite $(R)$-enantiomer in $74 \%$ ee with this mutant (Table 1, entry 26). This highlights the critical importance of the methoxy substituents on enantioselectivity. The influence of methoxy substituents on the substrate (irrespective of their substitution pattern) suggest that the electron density on the arene may play a critical role in positioning one prochiral face of the substrate to the $\mathrm{Ir}-\mathrm{H}$ moiety.

\section{Outlook}

The results presented herein demonstrate that structurebased computational amino acid sequence optimization with Rosetta Design allows to identify hCAII mutants with significantly increased affinity for an Ir-catalyst bearing a arylsulfonamide moiety. Improved proteincofactor stability correlates with both increased activity and enantioselectivity. Higher TON may relate to a reduced weight of non-productive conformations of the cofactor-protein assembly. Combining designed hCAII mutations with more hydrophobic Ir-catalyst $\mathbf{2}$ yields the most $(S)$-selective ATHase reported to date. The presence of methoxy substituents on the prochiral imine was shown to determine which enantiomer of the amine is produced preferentially. Structural characterization of catalyst $\mathbf{2}$ binding to hCAII $\mathbf{a} 2$ illustrates how embedding 
the catalyst within the protein in a fixed orientation contributes to increased selectivity. Future experiments will aim at applying Rosetta Design for the optimization of other artificial metalloenzymes including in silico scanning of metal cofactor diversity. In addition, to further increase the stereoselectivity it can be envisaged to utilize computational models of the $(R)$ - and $(S)$-reaction transition states in the Rosetta protein sequence optimization procedure. ${ }^{40,54}$

\section{ASSOCIATED CONTENT}

General information on computational design, cofactor and substrate synthesis and protein production, experimental details, additional data. This material is available free of charge via the Internet at http://pubs.acs.org.

\section{AUTHOR INFORMATION}

\section{Corresponding Author}

thomas.ward@unibas.ch

\section{Author Contributions}

†These authors contributed equally.

\section{Notes}

The authors declare no competing financial interest.

\section{ACKNOWLEDGMENT}

T.R.W thanks the Swiss National Science Foundation for financial support (grant 200020_144354 as well as the National Center of Competence in Research "Molecular Systems Engineering"). Prof. C. Fierke is thanked for the hCAII plasmid and Umicore for a loan of precious metals. The authors thank J. Zhao for help with protein production, T. Sharp and F. Stanger for help with affinity measurements, Prof. T. Schirmer and N. Schmitz for help with structure refinement.

\section{REFERENCES}

(1) Yu, F.; Cangelosi, V. M.; Zastrow, M. L.; Tegoni, M.; Plegaria, J. S.; Tebo, A. G.; Mocny, C. S.; Ruckthong, L.; Qayyum, H.; Pecoraro, V. L. Chem. Rev. 2014, 114, 3495.

(2) Lewis, J. C. ACS Catal. 2013, 3, 2954

(3) Dürrenberger, M.; Ward, T. R. Curr. Opin. Chem. Biol. 2014, 19, 99.

(4) Hyster, T. K.; Arnold, F. H. Isr. J. Chem. 2015, 55, 14.

(5) Renata, H.; Wang, Z. J.; Arnold, F. H. Angew. Chemie Int. Ed. 2015, 54, 3351 .

(6) Rioz-Martínez, A.; Roelfes, G. Curr. Opin. Chem. Biol. 2015, 25,80 .

(7) Maity, B.; Fujita, K.; Ueno, T. Curr. Opin. Chem. Biol. 2015, 25, 88.

(8) Onoda, A.; Hayashi, T. Curr. Opin. Chem. Biol. 2015, 25, 133.
(9) Caserta, G.; Roy, S.; Atta, M.; Artero, V.; Fontecave, M. Curr. Opin. Chem. Biol. 2015, 25, 36.

(10) Lu, Y.; Yeung, N.; Sieracki, N.; Marshall, N. M. Nature 2009, 460,855 .

(11) Song, W. J.; Tezcan, F. A. Science 2014, 346, 1525

(12) Letondor, C.; Humbert, N.; Ward, T. R. Proc. Natl. Acad. Sci. 2005, 102, 4683

(13) Letondor, C.; Pordea, A.; Humbert, N.; Ivanova, A.; Mazurek, S.; Novic, M.; Ward, T. R. J. Am. Chem. Soc. 2006, 128, 8320.

(14) Pordea, A.; Creusa, M.; Panek, J.; Duboc, C.; Mathis, D.; Novic, M.; Ward, T. R. J. Am. Chem. Soc. 2008, 130, 8085.

(15) Creus, M.; Pordea, A.; Rossel, T.; Sardo, A.; Letondor, C.; Ivanova, A.; Letrong, I.; Stenkamp, R. E.; Ward, T. R. Angew. Chemie Int. Ed. 2008, 47, 1400

(16) Pierron, J.; Malan, C.; Creus, M.; Gradinaru, J.; Hafner, I.; Ivanova, A.; Sardo, A.; Ward, T. R. Angew. Chemie Int. Ed. 2008, 47,701 .

(17) Dürrenberger, M.; Heinisch, T.; Wilson, Y. M.; Rossel, T.; Nogueira, E.; Knörr, L.; Mutschler, A.; Kersten, K.; Zimbron, M. J.; Pierron, J.; Schirmer, T.; Ward, T. R. Angew. Chemie Int. Ed. 2011, 50, 3026.

(18) Köhler, V.; Mao, J.; Heinisch, T.; Pordea, A.; Sardo, A.; Wilson, Y. M.; Knörr, L.; Creus, M.; Prost, J.-C.; Schirmer, T.; Ward, T. R. Angew. Chemie Int. Ed. 2011, 50, 10863.

(19) Lo, C.; Ringenberg, M. R.; Gnandt, D.; Wilson, Y.; Ward, T. R. Chem. Commun. 2011, 47, 12065.

(20) Mayer, C.; Gillingham, D. G.; Ward, R.; Hilvert, D. Chem. Commun. 2011, 47, 12068.

(21) Matsuo, T.; Imai, C.; Yoshida, T.; Saito, T.; Hayashi, T.; Hirota, S. Chem. Commun. 2012, 48, 1662.

(22) Fukumoto, K.; Onoda, A.; Mizohata, E.; Bocola, M.; Inoue, T.; Schwaneberg, U.; Hayashi, T. ChemCatChem 2014, 6, 1229.

(23) Hyster, T. K.; Knörr, L.; Ward, T. R.; Rovis, T. Science 2012, 338,500 .

(26) Farwell, C. C.; Mcintosh, J. A.; Hyster, T. K.; Wang, Z. J.; Arnold, F. H. J. Am. Chem. Soc. 2014, 136, 8766. Bordeaux, M.; Tyagi, V.; Fasan, R. Angew. Chemie Int. Ed. 2015, 54, 1744.

Yang, H.; Srivastava, P.; Zhang, C.; Lewis, J. C. ChemBioChem 2014, 15, 223 . 
Bos, J.; Fusetti, F.; Driessen, A. J. M.; Roelfes, G. Angew. Chemie Int. Ed. 2012, 51, 7472.

(30) Khare, S. D.; Kipnis, Y.; Greisen, P.; Takeuchi, R.; Ashani, Y.; Goldsmith, M.; Song, Y.; Gallaher, J. L.; Silman, I.; Leader, H.; Sussman, J. L.; Stoddard, B. L.; Tawfik, D. S.; Baker, D. Nat. Chem. Biol. 2012, 8, 294.

(31) Wang, Z. J.; Renata, H.; Peck, N. E.; Farwell, C. C.; Coelho, P. S.; Arnold, F. H. Angew. Chemie Int. Ed. 2014, 53, 6810.

(32) Hyster, T. K.; Farwell, C. C.; Buller, A. R.; McIntosh, J. a; Arnold, F. H. J. Am. Chem. Soc. 2014, 136, 15505.

(33) Kiss, G.; Nihan, C.; Moretti, R.; Baker, D.; Houk, K. N. Angew. Chemie Int. Ed. 2013, 52, 5700.

(34) Korendovych, I. V; DeGrado, W. F. Curr. Opin. Struct. Biol. 2014, 27, 113.

(35) Zastrow, M. L.; Pecoraro, V. L. Biochemistry 2014, 53, 957.

(36) Fleishman, S. J.; Whitehead, T. A.; Ekiert, D. C.; Dreyfus, C.; Corn, J. E.; Strauch, E.; Wilson, I. A.; Baker, D. Science. 2011, 332,816 .

(37) Tinberg, C. E.; Khare, S. D.; Dou, J.; Doyle, L.; Nelson, J. W.; Schena, A.; Jankowski, W.; Kalodimos, C. G.; Johnsson, K.; Stoddard, B. L.; Baker, D. Nature 2013, 501, 212.

(38) Mills, J. H.; Khare, S. D.; Bolduc, J. M.; Forouhar, F.; Mulligan, V. K.; Lew, S.; Seetharaman, J.; Tong, L.; Stoddard, B. L.; Baker, D. J. Am. Chem. Soc. 2013, 135, 13393.

(39) Röthlisberger, D.; Khersonsky, O.; Wollacott, A. M.; Jiang, L.; DeChancie, J.; Betker, J.; Gallaher, J. L.; Althoff, E. a; Zanghellini, A.; Dym, O.; Albeck, S.; Houk, K. N.; Tawfik, D. S.; Baker, D. Nature 2008, 453, 190.

(40) Siegel, J. B.; Zanghellini, A.; Lovick, H. M.; Kiss, G.; Lambert, A. R.; St Clair, J. L.; Gallaher, J. L.; Hilvert, D.; Gelb, M. H.; Stoddard, B. L.; Houk, K. N.; Michael, F. E.; Baker, D. Science 2010, 329, 309.

(41) Jiang, L.; Althoff, E. a; Clemente, F. R.; Doyle, L.; Röthlisberger, D.; Zanghellini, A.; Gallaher, J. L.; Betker, J. L.;
Tanaka, F.; Barbas, C. F.; Hilvert, D.; Houk, K. N.; Stoddard, B. L.; Baker, D. Science 2008, 319, 1387.

(42) Bjelic, S.; Nivón, L. G.; Çelebi-Ölçüm, N.; Kiss, G.; Rosewall, C. F.; Lovick, H. M.; Ingalls, E. L.; Gallaher, J. L.; Seetharaman, J.; Lew, S.; Montelione, G. T.; Hunt, J. F.; Michael, F. E.; Houk, K. N.; Baker, D. ACS Chem. Biol. 2013, 8, 749.

(43) Monnard, F. W.; Nogueira, E. S.; Heinisch, T.; Schirmer, T.; Ward, T. R. Chem. Sci. 2013, 4, 3269.

(44) Schwizer, F.; Köhler, V., Dürrenberger, M.; Knörr, L., Ward, T. R. ACS Catalysis 2013, 3, 1752 .

(45) Richter, F.; Leaver-Fay, A.; Khare, S. D.; Bjelic, S.; Baker, D. PLoS One 2011, 6, e19230.

(46) Nivón, L. G.; Moretti, R.; Baker, D. PLoS One 2013, 8, e59004.

(47) Fleishman, S. J.; Leaver-Fay, A.; Corn, J. E.; Strauch, E. M.; Khare, S. D.; Koga, N.; Ashworth, J.; Murphy, P.; Richter, F.; Lemmon, G.; Meiler, J.; Baker, D. PLoS One 2011, 6, e20161.

(48) Monnard, F. W.; Nogueira, E. S.; Heinisch, T.; Schirmer, T.; Ward, T. R. Chem. Sci. 2013, 4, 3269.

(49) Rappé, A. K.; Casewit, C. J.; Colwell, K. S.; Goddard III, W. A.; Skiff, W. M. J. Am. Chem. Soc. 1992, 114, 10024.

(50) Fleishman, S. J.; Khare, S. D.; Koga, N.; Baker, D. Protein Sci. 2011, 20, 753 .

(51) Chen, R. F.; Kernohan, J. C. J. Biol. Chem. 1967, 5813.

(52) Qin, L.; Srivastava, D. K. Biochemistry 1998, 3499.

(53) Monnard, F. W.; Heinisch, T.; Nogueira, E. S.; Schirmer, T.; Ward, T. R. Chem. Commun. 2011, 47, 8238.

(54) Davis, I. W.; Raha, K.; Head, M. S.; Baker, D. Protein Sci. 2009, $18,1998$. 
Table of Content Art Work:
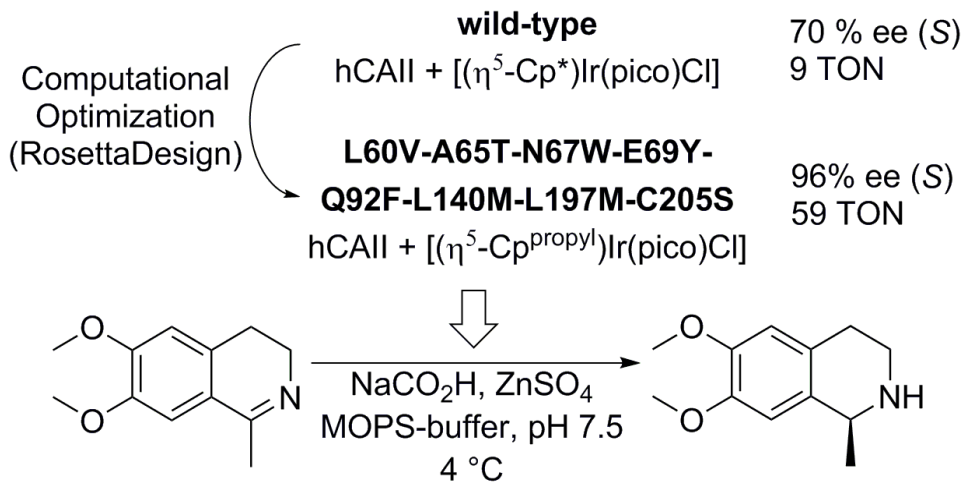